\title{
Mikroklima Özelliğine Sahip İklim Koşullarında Meteorolojik Verilerle İlişkili Partiküler Kirlilik (PM10) Karakteristikleri: Iğdır Örneği
}

\author{
Aysun ALTIKAT ${ }^{1 *(1)}$ \\ ${ }^{1}$ Iğdır Üniversitesi Mühendislik Fakültesi Çevre Mühendisliği Bölümü
}

Geliş / Received: 30/11/2018, Kabul / Accepted: 09/10/2019

\begin{abstract}
Öz
$\mathrm{Bu}$ çalışmada mikroklima özelliğine sahip Iğdır ilinde meteorolojik faktörlerin partiküler kirlilik $\left(\mathrm{PM}_{10}\right)$ miktarındaki değişimleri bir yıllık zaman periyodunda mevsimsel olarak incelenmiştir. Araştırmada bağıl nem, rüzgâr yönü, rüzgâr hızı, hava basıncı ve hava sıcaklı̆ğ meteorolojik veriler; atmosferdeki $\mathrm{PM}_{10}$ konsantrasyonu ise partiküler kirlilik düzeyi olarak dikkate alınmıştır. Faktörler parametrik olmayan özelliğe sahip olması nedeniyle Spearman's korelasyon testine tabi tutularak birbirleriyle olan değişimleri belirlenmiştir. Yapılan korelasyon testi sonuçlarına göre il genelinde $\mathrm{PM}_{10}$ değişimine kış ve sonbahar dönemlerinde; hava basıncı ve rüzgâr hızı, ilkbaharda; nem ve rüzgâr yönü, yaz periyodunda ise; rüzgâr yönü ve rüzgâr hızı en çok etkili olan meteorolojik parametreler olarak tespit edilmiştir. Ayrıca ortalama $\mathrm{PM}_{10}$ miktarının kış, ilkbahar, yaz ve sonbahar periyotlarında sirasiyla $164.7 \mu \mathrm{gm}^{-3}, 84 \mu \mathrm{gm}^{-3}, 117 \mu \mathrm{gm}^{-3}$ ve $181 \mu \mathrm{gm}^{-3}$ ve yıllık ortalama $\mathrm{PM}_{10}$ değerinin $182.23 \mu \mathrm{gm}^{-3}$ olduğu belirlenmiştir. Bu değer dikkate alındığında Iğdır ilindeki $\mathrm{PM}_{10}$ düzeyinin, Hava Kalitesi Değerlendirme ve Yönetimi Yönetmeliğinin belirlemiş olduğu 24 saatlik $\mathrm{PM}_{10}$ limit değeri olan 50 $\mu \mathrm{gm}^{-3}$ 'den çok daha fazla olduğu sonucuna varılmıştır. Bu aşım yılın tüm günlerinde gözlenmiştir.
\end{abstract}

Anahtar Kelimeler: $\mathrm{PM}_{10}$, iklim, rüzgâr yönü, rüzgâr hızı, hava basıncı

\section{Characteristics of Particulate Matter Pollution (PM10) and Their Relationships with Meteorological \\ Elements in Micro-Climate Conditions: Example of Iğdır}

\begin{abstract}
In this study, in seasonal periods in one year, it was examined the relationship between the particulate matter $\left(\mathrm{PM}_{10}\right)$ concentration and meteorological data at the micro-climate conditions in Iğdır province. For this purpose, it was evaluated relative humidity, wind direction, wind speed, air pressure and air temperature as meteorological data. In addition; the concentration of $\mathrm{PM}_{10}$ in air was taken into account as particulate matter pollution degree. Spearman's correlation test was applied in the factors, owing to having non-parametric properties, to determine the relationship between the meteorological factors and $\mathrm{PM}_{10}$ concentrations. The most effective meteorological parameters to the $\mathrm{PM}_{10}$ level were determined air pressure and wind speed in the winter and autumn, air humidity and wind direction in the spring, and also wind direction and wind speed in the summer. In addition, average amount of $\mathrm{PM}_{10}$ was found $164.7 \mu \mathrm{gm}^{-3}, 84 \mu \mathrm{gm}^{-3}, 117 \mu \mathrm{gm}^{-3}$, and $181 \mu \mathrm{gm}^{-3}$ in winter, spring, summer and autumn periods, respectively, and also, the mean annual $\mathrm{PM}_{10}$ value was 182.23 $\mu \mathrm{gm}^{-3}$. When this value is taken into consideration, it is concluded that the $\mathrm{PM}_{10}$ level in Iğdır province is much

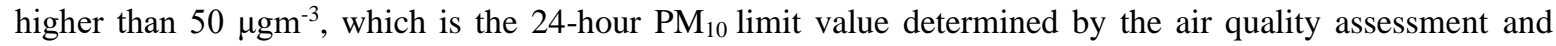
management regulation. This exceedance was observed during the year.
\end{abstract}

Keywords: $\mathrm{PM}_{10}$, climate, wind direction, wind speed, air pressure 


\section{Giriş}

Iğdır, Doğu Anadolu Bölgesi'nin en doğusunda 39'-41' kuzey paralelleri ile 43'$45^{\prime}$ doğu meridyenleri arasında yer almaktadır. İlin Ermenistan, Nahcivan ve İran ile sınırı olup yaklaşık $3585 \mathrm{~m}^{2}$ yüz ölçümüne sahiptir. Karasal iklim koşullarının gözlendiği ilde yıllık ortalama yağış ve ortalama sıcaklık sırasıyla, 256.4 $\mathrm{mm}$ ve $11.6^{\circ} \mathrm{C}$ 'dir. Her ne kadar karasal iklim özelliğine sahip olsa da Doğu Anadolu Bölgesi'nin diğer kesimlerinde görülen şiddetli kara ikliminden etkilenmez. Bunun en önemli nedeni çevresinde bulunan Ağrı Dağı (5137 m) gibi yüksek alanlara göre ilin alçakta $(850 \mathrm{~m})$ olmasıdır. Bu coğrafi konum sayesinde ilde mikro-klima özelliği gözlenmektedir. Bölgede yıllık ortalama basınç $916 \mathrm{mb}$, ortalama bağıl nem ise \%63 civarındadır. İl genelinde çoğunlukla batı sektörlü rüzgâr yönü hâkimdir. Batı sektörlü rüzgârları kuzey rüzgârları ve az da olsa doğu sektörlü rüzgârlar takip etmektedir. Bozkır bitki örtüsüne sahip olan ilin yüksek kesimlerinde dağ stepi ve alpin çayırları mevcuttur. İlde orman niteliği taşıyan bölge bulunmamaktadır. Sadece Büyük ve Küçük Ağrı Dağları'nın kuzey bölümlerinde huş ağaçlarından oluşan küçük koruluklar vardır. Iğdır üç ülkeye sınırı bulunması, zengin biyolojik kaynakları, nispeten 1lıman karakterde iklim özellikleriyle gelişmeye elverişli olmasına rağmen ilin çok ciddi çevresel problemleri bulunmaktadır. $\mathrm{Bu}$ problemlerden en önemlisi de yalnızca 1sınma amaçlı yakıt tüketimine bağlanamayacak boyutlarda, yılın tamamını kapsayan hava kirliliğidir.

Hava kirliliği her ne kadar kentsel yerleşim alanlarında daha yoğun hissedilse de küresel anlamda insan sağlığını önemli düzeyde tehdit etmektedir (Kolehmainen et al., 2001). Yapılan araştırmalarda hava kirlilik düzeyinin; halk sağlığı (Garcia et al., 2015), ekoloji (Tambo et al., 2016) ve küresel 1sınma üzerinde (Zheng et al., 2016) önemli etkileri olduğu belirlenmiştir. Kronik solunum problemleri, göz tahrişi, nefes darlığ 1 ve kanser gibi pulmoner ve kardiyovasküler hastalıklar hava kirliliğinin neden olduğu önemli ve ciddi sağlık sorunlarından bazılarıdır (Bai et.al., 2016).

Hava kirlilik düzeyinin tespitinde yararlanılan en temel gösterge partiküler madde (PM) miktarıdır. Partiküler maddenin ana kaynağı olarak; araçlardan kaynaklanan egzoz emisyonları, enerji santralleri ve endüstriyel prosesler sayılabilir. Yapılan çalışmalarda çoğunlukla $10 \mu$ m'den küçük çaplı parçacıklar $\left(\mathrm{PM}_{10}\right)$ partiküler madde kategorisinde değerlendirilmiştir (Liu et al., 2004). Avrupa Birliği hava kirlilik standartlarında (European Air (2008/50/EC)) $\mathrm{PM}_{10}$ için y1llık ortalama sınır değeri $40 \mathrm{gml}^{-1}$ ve 24 saat konsantrasyon limiti $50 \mathrm{gm}^{-3}$ olarak belirlenmiştir. Türkiye'de ise yürürlükte olan Hava Kalitesi Değerlendirme ve Yönetimi Yönetmeliği'ne (HKDYY) göre 24 saatlik $\mathrm{PM}_{10}$ standard1 $50 \mu \mathrm{gm}^{-3}$ tür ve bu ortalama $80 \mu \mathrm{gm}^{-3}$ 'ü aştığında emisyonlara yönelik kısıtlamalar uygulanmaktadır (Ceylan and Bulkan, 2018).

Hava kirliliği üzerine yapılan konsantrasyonunun meteorolojik koşullara bağlı olarak değiştiği belirtilmiştir (Choi et al., 2008; Akyüz and Çabuk, 2009). Bu değişim; rüzgâr hızı ve hava sıcaklığı gibi meteorolojik faktörlerden kaynaklandığ gibi, enerji ve fosil yakıt tüketimi gibi dolaylı yollardan da meydana 
gelebilmektedir. Hava şartlarındaki değişim, kirleticilerin belirli bir alan içinde yayılmasına, başka bölgelere taşınarak uzaklaştırılmasına neden olmaktadır. Bu etkilerle atmosferdeki kirletici konsantrasyonu değişmektedir (Tian et al., 2014).

Hava kirlilik düzeyinin meteorolojik faktörlerle olan ilişkisinin belirlenmesi yoluyla, farklı meteorolojik şartlarda atmosferdeki kirliliğin tahmin edilmesi ve azaltılmasına yönelik kentsel tasarımlar yapılmaktadır. Özellikle hâkim rüzgâr yönünün bilinmesiyle şehir çevresinde bulunan ve kirletici özelliğe sahip fabrika, taş ocağ gibi işletmelerin hava kalitesi üzerindeki olumsuz etkileri azaltılabilir. Atmosferdeki kirlilik düzeyine; $\mathrm{SO}_{2}, \mathrm{NO}$, $\mathrm{NO}_{2}, \mathrm{NOx}, \mathrm{O}_{3}$ gibi gazların etkilerinin de olduğu bilinmektedir. Iğdır ili bulunduğu coğrafi konum nedeniyle hava sirkülasyonun çok az olduğu, özellikle kış aylarında çok yüksek oranda kirliliğinin tespit edildiği Türkiye'nin en kötü havasına sahip illerinden biridir. Bu araştırma ile kirliliğin diğer meteorolojik faktörlerle olan etkileri incelenmiştir. $\mathrm{Bu}$ sayede hava kirleticilerin meteorolojik faktörlerden nasıl etkileneceği net bir şekilde ortaya konulmuştur.

\section{Materyal ve Yöntem}

\subsection{Materyal}

Araştırmada 2016-2017 yıllarına ait $\mathrm{PM}_{10}$ konsantrasyonları ve meteorolojik verilerden yararlanılmıştır. Hava sıcaklığı, bağıl nem, hava basıncı, rüzgâr yönü ve rüzgâr hızı meteorolojik veriler kapsamında değerlendirilmiştir. Çalışmada kullanılan tüm veriler Çevre ve Şehircilik Bakanlığı Ulusal Hava İzleme Ağı'ndan temin edilmiştir (ÇŞB, 2018). İl genelinde partiküler madde kirliliğini daha iyi yorumlamak amaciyla veriler mevsimlere göre gruplandırılarak incelenmiştir. Buna göre kış periyodunda; Aralık, Ocak, Şubat, ilkbahar periyodunda; Mart, Nisan, Mayıs, yaz periyodunda; Haziran, Temmuz, Ağustos ve sonbahar periyodunda ise Eylül, Ekim ve Kasım ayları dikkate alınmıştır.

\subsection{Yöntem}

Araştırmada ölçüm istasyonundan günlük olarak elde edilen veriler arasında bazı verilerin ölçülemediği belirlenmiştir. Bu eksik veriler lineer interpolasyon yöntemi ile tamamlanmıştır (Januchs et al., 2015). Meteorolojik veriler ile $\mathrm{PM}_{10}$ konsantrasyonu arasındaki ilişkiyi belirlemek amaciyla Spearman's korelasyon testleri yapılmış ve anlam düzeyleri belirlenmiştir. Spearman's korelasyon testi hava kalitesi ile ilgili yapılan çalışmalarda değişkenler arasındaki bağıntıyı açıklamak amacıyla kullanılan en iyi korelasyon testi olarak literatürde yerini almıştır (Maraziotis et al.,2008). Bu testte iki değişken arasında mukayese yapılmaktan ziyade birbirleri ile olan değişimleri incelenmektedir. Testin yorumlanması korelasyon katsayılarının dikkate alınmasiyla yapılmaktadir. Korelasyon katsayısı 0.5 'ten küçük olan faktörler arasındaki ilişki "zayıf bağıntı" olarak kabul edilir. $\mathrm{Bu}$ değer $0.5-0.7$ arasında ise faktörler arasındaki değişimin "orta düzeyde bağıntllı" olduğu sonucuna varılır. Korelasyon katsayısının 0.7 'den büyük olması durumunda ise faktörler arasında "yüksek oranda bağıntı" olduğu anlaşılmaktadır. Araştırmada rüzgâr yönü açı birimi (derece) olarak dikkate alınmıştır. Rüzgâr yönünün derece cinsinden karşıllkları ise Şekil 2.1'de verilmiştir. 
Karakteristikleri: Iğdır Örneği

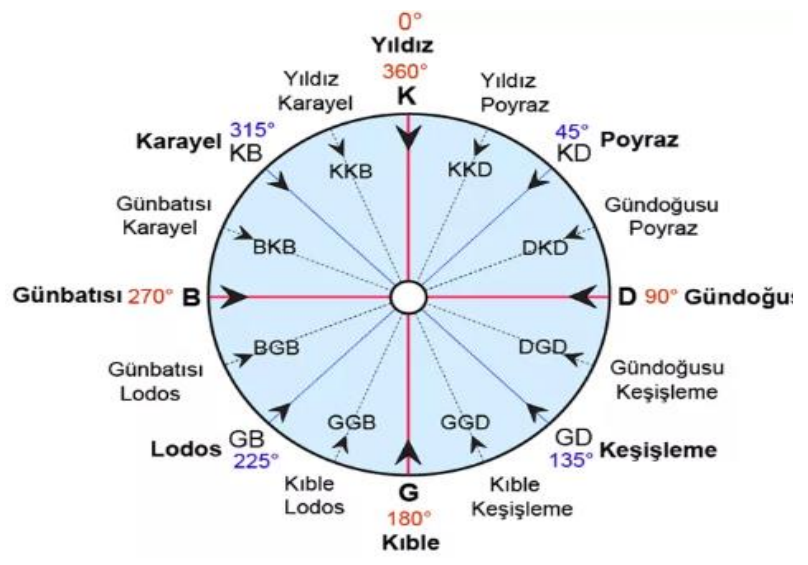

Şekil 2.1. Rüzgâr yönleri ve açı cinsinden karşılıkları

\section{Bulgular}

\subsection{Kış Periyoduna İlişkin Sonuçlar}

Araştırmada, 1sınma dönemi olan ve ciddi yakıt tüketiminin olduğu kış periyodunda, partiküler madde miktarının ortalama değerinin $\quad 164.7 \quad \mu \mathrm{gm}^{-3} \quad$ olduğu belirlenmiştir. HKDYY'ne göre Türkiye'de kabul edilen $\mathrm{PM}_{10}$ konsantrasyonunun limit değerleri 24 saatte $50 \mu \mathrm{gm}^{-3}$, y1llık bazda ise $40 \mu^{-3}$ 'tür. $\mathrm{Bu}$ sonuçlardan yola çıkıldığında il genelinde tüm kış periyodu boyunca $\mathrm{PM}_{10}$ miktarının sınır değerlerinin çok üstünde olduğu Şekil 3.1'den anlaşılmaktadır.

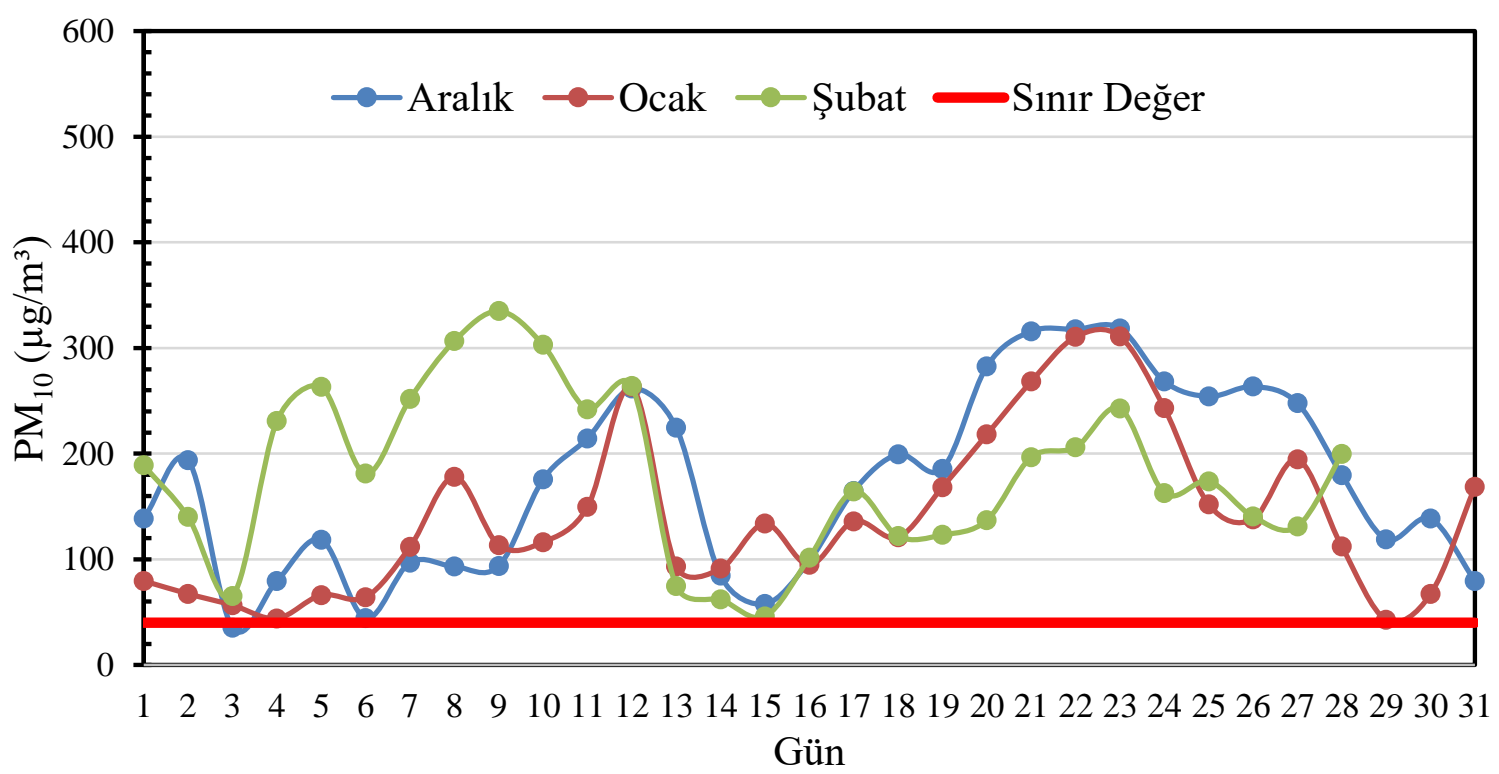

Şekil 3.1. Partiküler madde miktarının kış periyodundaki değişimi

pozitif olmasından da anlaşılacağı gibi hava basınc1 ve $\mathrm{PM}_{10}$ miktarı arasında doğru

Kış dönemine ait partiküler maddenin meteorolojik faktörlere göre değişimini belirlemek amaciyla yapılan Spearman's korelasyon testine ait korelasyon katsayıları Çizelge 3.1'de verilmiştir. Çizelge incelendiğinde hava basincı ile atmosferdeki $\mathrm{PM}_{10}$ düzeyi arasındaki korelasyon katsayısının 0.672 olduğu görülmektedir. Bu katsayı hava basıncı ile $\mathrm{PM}_{10}$ arasında kuvvetliye yakın orta düzeyde bir korelasyon olduğunu açıklamaktadır. Korelasyon katsayısının orantılı bir değişim olduğu belirlenmiştir. Kış periyodunda rüzgâr hızı ile $\mathrm{PM}_{10}$ miktarındaki değişim arasında -0.790 değerinde ters orantılı bir korelasyon saptanmıştır (Çizelge 3.1). Bu noktadan hareketle rüzgâr hızı ve $\mathrm{PM}_{10}$ miktarındaki değişim arasında kuvvetli düzeyde bir korelasyonun olduğu anlaşılmaktadır. Kış döneminde rüzgâr hızının artmasıyla atmosferdeki $\mathrm{PM}_{10}$ miktarının da azalma eğilimine girdiği belirlenmiştir. 
Mikroklima Özelliğine Sahip İklim Koşullarında Meteorolojik Verilerle İlişkili Partiküler Kirlilik $\left(\mathrm{PM}_{10}\right)$

Karakteristikleri: Iğdır Örneği

Çizelge 3.1. Kış dönemine ait korelasyon katsayıları

\begin{tabular}{|c|c|c|c|c|c|c|}
\hline & Bn & $\mathbf{R y}$ & Hb & $\mathbf{R h}$ & Hs & $\mathbf{P M}_{10}$ \\
\hline Bn & 1.000 & $0.562^{* *}$ & $-0.438^{* * *}$ & $0.222^{*}$ & -0.082 & $-0.213^{*}$ \\
\hline $\mathbf{R y}$ & $0.562^{* *}$ & 1.000 & $-0.478^{* *}$ & $0.252^{*}$ & $-0.415^{* *}$ & $-0.303^{* *}$ \\
\hline $\mathbf{H b}$ & $-0.438^{* *}$ & $-0.478^{* *}$ & 1.000 & $-0.726^{* *}$ & $0.322^{* *}$ & $0.672^{* *}$ \\
\hline $\mathbf{R h}$ & $0.222^{*}$ & $0.252^{*}$ & $-0.726^{* *}$ & 1.000 & $-0.332^{* * *}$ & $-0.790^{* *}$ \\
\hline Hs & -0.082 & $-0.415^{* *}$ & $0.322^{* *}$ & $-0.332^{* *}$ & 1.000 & $0.284^{* *}$ \\
\hline $\mathbf{P M}_{10}$ & $-0.213^{*}$ & $-0.303^{* *}$ & $0.672^{* *}$ & $-0.790^{* *}$ & $0.284^{* *}$ & 1.000 \\
\hline
\end{tabular}

Araştırmada bağıl nem, rüzgâr yönü ve hava sicaklığı ile $\mathrm{PM}_{10}$ konsantrasyonu arasında anlamlı fakat zayıf bir korelasyon belirlenmiştir. Kış periyodunda rüzgâr yönü ve bağıl nem düzeyi ile $\mathrm{PM}_{10}$
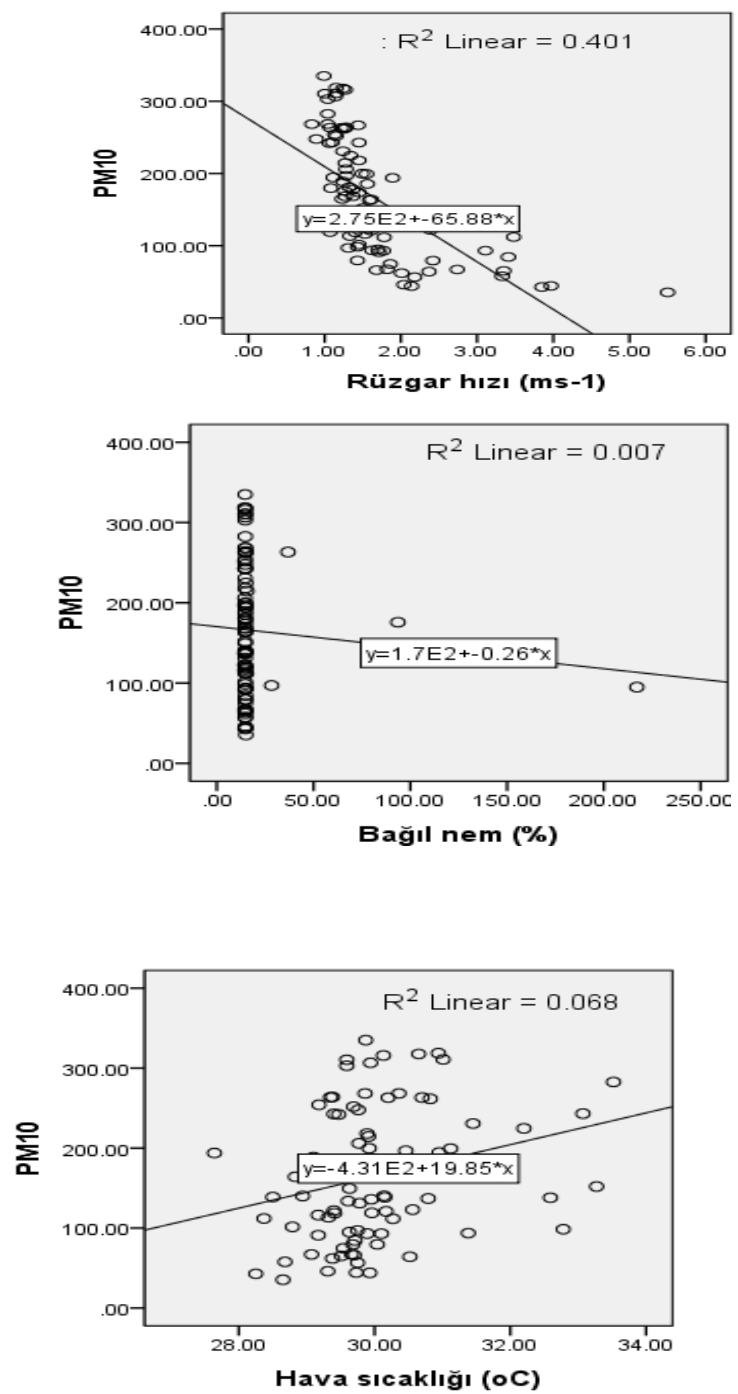

konsantrasyonu arasında ters yönlü bir ilişki belirlenirken, partiküler madde miktarı hava sıcaklığı ile doğru orantılı bir değişim göstermiştir. Meteorolojik faktörler ile $\mathrm{PM}_{10}$ konsantrasyonu arasinda belirlenen ilişkiler Şekil 3.2'de verilmiştir.
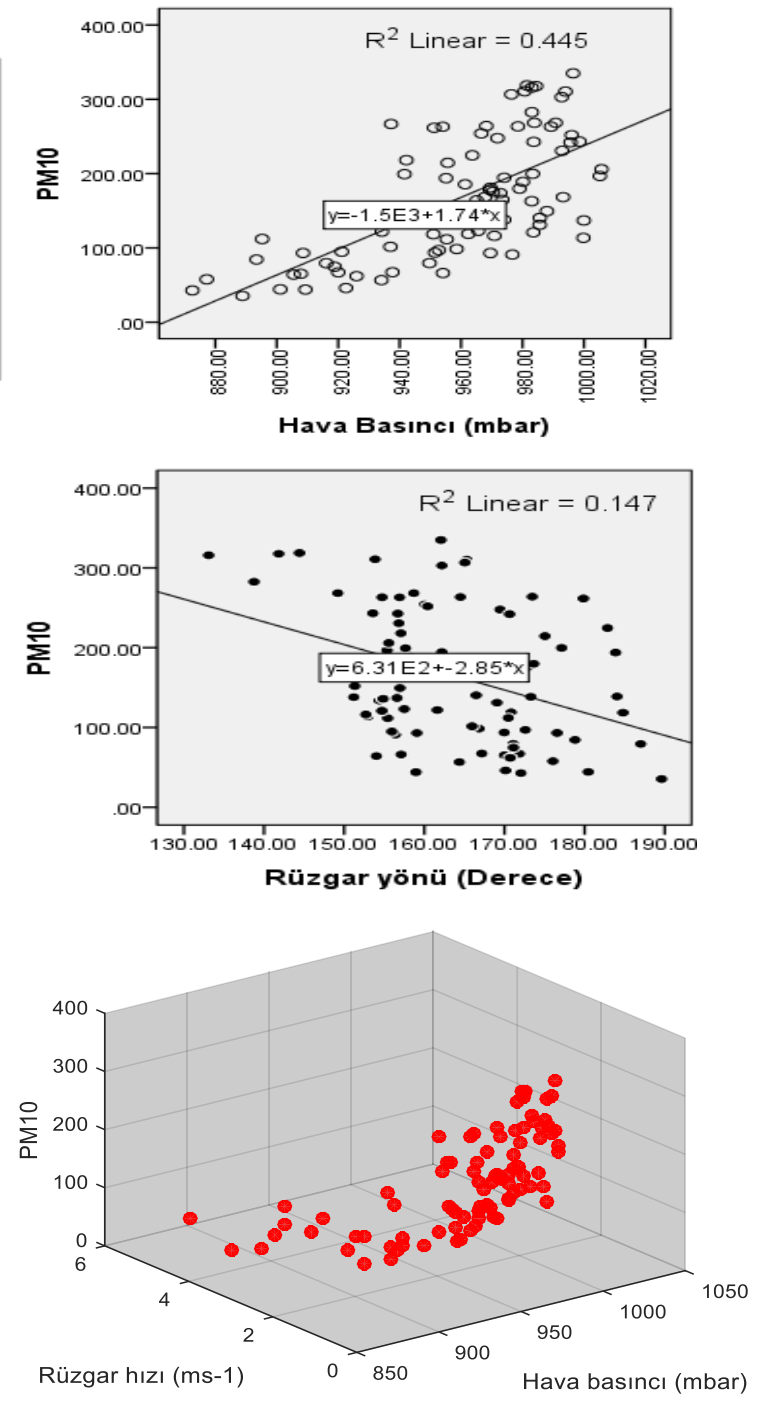
Şekil 3.2. Kış periyodunda $\mathrm{PM}_{10}$ konsantrasyonunun meteorolojik faktörlerle değişimi

\section{2. İlkbahar Periyoduna İlişkin Sonuçlar}

İlkbahar döneminde partiküler madde

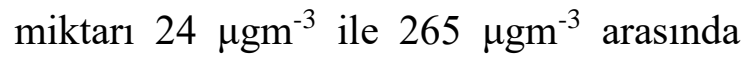
değişim göstermiş ve mevsim boyunca ortalama $84{\mu \mathrm{gm}^{-3}}^{-3}$ düzeyine ulaşmıştır (Şekil 3.3). Değerler incelendiğinde ilkbahar sezonunda sadece 14 günlük süre zarfında $\mathrm{PM}_{10}$ düzeyinin limit değerin altında kaldığ 1 belirlenmiştir. İlkbahar periyodundaki $\mathrm{PM}_{10}$ değişimine ilişkin korelasyon katsayıları incelendiğinde (Çizelge 3.2), partiküler maddenin bağıl nem ve rüzgâr yönü ile ortaya yakın zayıf düzeyde bir korelasyona sahip olduğu anlaşıılmaktadır. Kış periyodunda atmosferdeki bağıl nem miktarının azalması ile partiküler madde miktarı da azalmıştır. Buna ilaveten rüzgâr yönü güney doğudan güney batıya doğru değiştiğinde $\mathrm{PM}_{10}$ miktarı da azalma eğilimine girmiştir (Şekil 3.4). Hava basınc1, rüzgâr hızı ve hava sıcaklığına ait korelasyon katsayıları incelendiğinde bu faktörler ile $\mathrm{PM}_{10}$ konsantrasyonu arasında anlamlı fakat zayıf bir ilişki olduğu söylenebilir. Hava basıncı ve rüzgâr hızı ile partiküler madde doğru orantılı değişiriken; bu değişim rüzgâr hızında ters orantılı bir şekilde değişmiştir. İlkbahar periyodunda partiküler madde miktarının atmosferik koşullar ile değişimleri Şekil 3.4'de verilmiş̧ir.

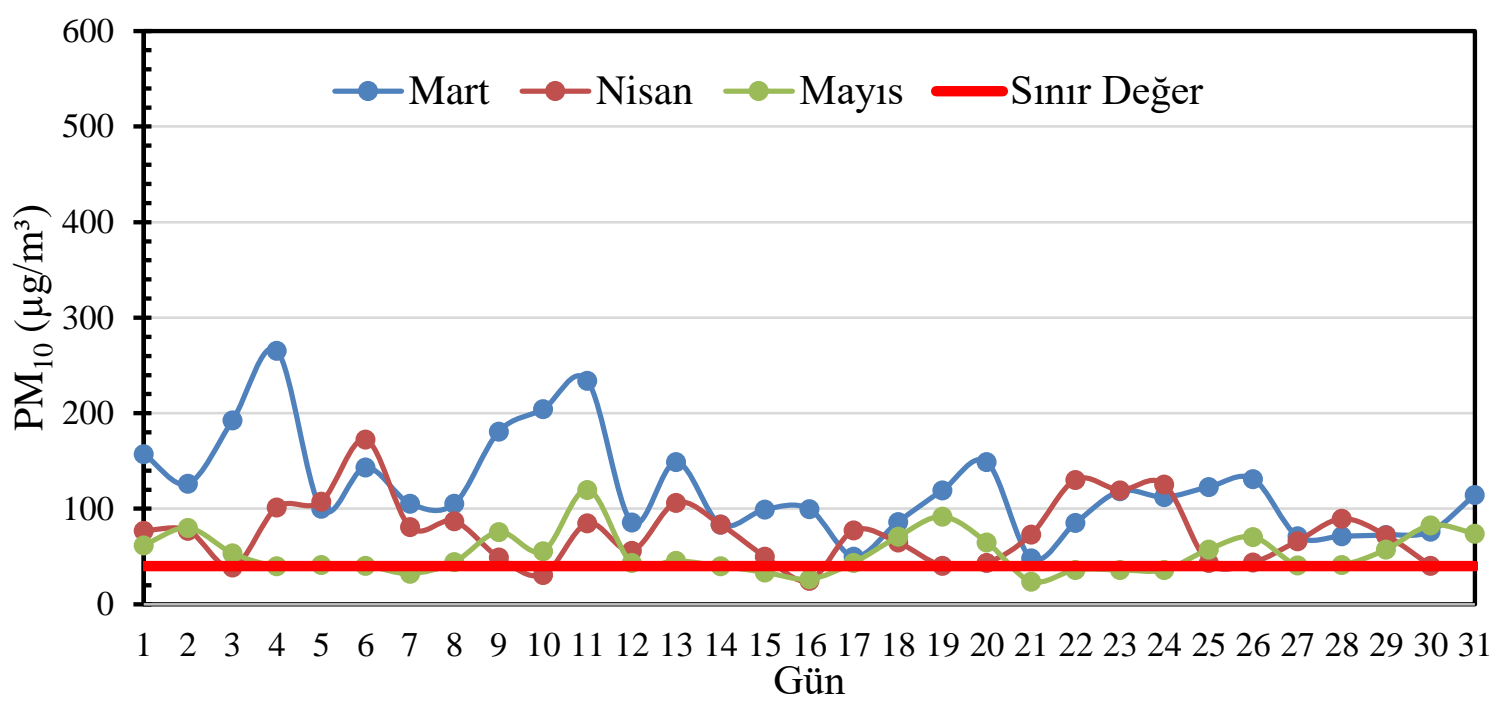

Şekil 3.3. Partiküler madde miktarının ilkbahar dönemindeki değişimi

Çizelge 3.2. İlk bahar dönemine ait korelasyon katsayıları

\begin{tabular}{|c|c|c|c|c|c|c|}
\hline & Bn & $\mathbf{R y}$ & $\mathbf{H b}$ & $\mathbf{R h}$ & Hs & PM10 \\
\hline Bn & 1.000 & $0.641^{* * *}$ & -0.099 & 0.178 & $-0.564^{* *}$ & $-0.549^{* * *}$ \\
\hline $\mathbf{R y}$ & $0.641^{* *}$ & 1.000 & -0.099 & $0.451^{* *}$ & $-0.324^{* * *}$ & $-0.460^{* * *}$ \\
\hline $\mathbf{H b}$ & -0.099 & -0.099 & 1.000 & $-0.388^{* *}$ & $0.286^{* *}$ & 0.170 \\
\hline $\mathbf{R h}$ & 0.178 & $0.451^{* *}$ & $-0.388^{* * *}$ & 1.000 & $-0.425^{* *}$ & $-0.433^{* * *}$ \\
\hline Hs & $-0.564^{* *}$ & $-0.324^{* *}$ & $0.286^{* *}$ & $-0.425^{* *}$ & 1.000 & $0.265^{*}$ \\
\hline $\mathbf{P M}_{10}$ & $-0.549^{* *}$ & $-0.460^{* *}$ & 0.170 & $-0.433^{* *}$ & $0.265^{*}$ & 1.000 \\
\hline
\end{tabular}



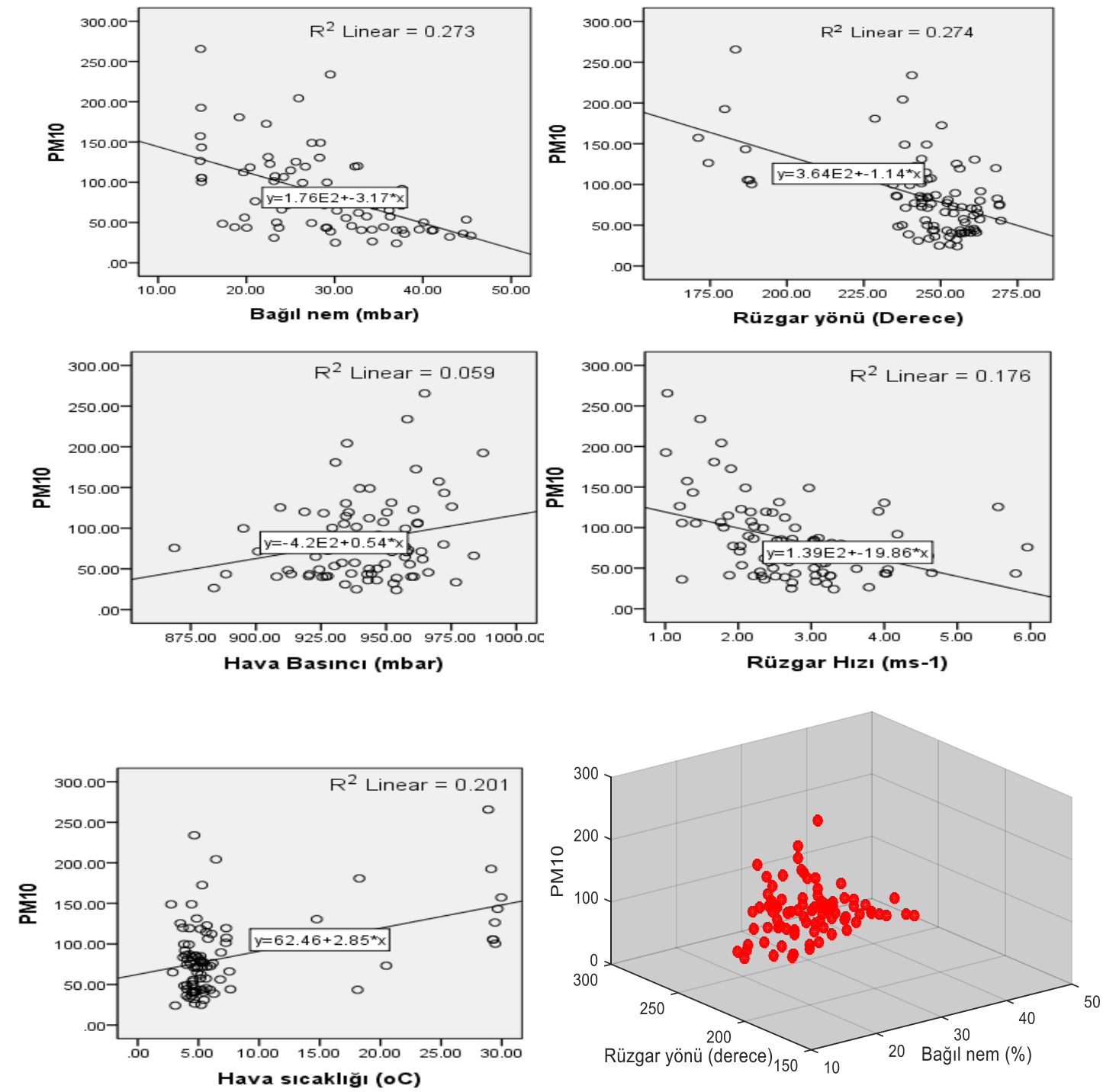

Şekil 3.4. İlkbahar periyodunda $\mathrm{PM}_{10}$ konsantrasyonunun meteorolojik faktörlerle değişimi

\subsection{Yaz Periyoduna İlişkin Sonuçlar}

Bu periyotta $\mathrm{PM}_{10}$ miktarı $33 \mu \mathrm{gm}^{-3}$ ile 210 $\mu \mathrm{gm}^{-3}$ arasında seyretmiş ve mevsim

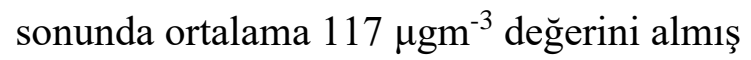
ve ölçüm aralığında sadece bir defa sınır değerin altında kalmıştır (Şekil 3.5). Korelasyon katsayıları incelendiğinde yaz döneminde $\mathrm{PM}_{10}$ miktarı ile meteorolojik faktörler arasındaki ilişkinin diğer dönemlere göre daha az olduğu belirlenmiştir. Bu dönemde rüzgâr yönü ile $\mathrm{PM}_{10}$ arasında ortaya yakın zayıf bir korelasyon belirlenirken hava sıcaklığı ile partiküler madde miktarında zayıf bir ilişki olduğu belirlenmiştir (Çizelge 3.3). Rüzgâr yönü güney batıdan kuzey batıya doğru değiştiğinde atmosferdeki $\mathrm{PM}_{10}$ miktarı da azalma eğilimine girmiştir. Buna ilaveten rüzgâr hızındaki artış $\mathrm{PM}_{10}$ miktarında nispeten azalmaya neden olmuştur (Şekil 3.6). 


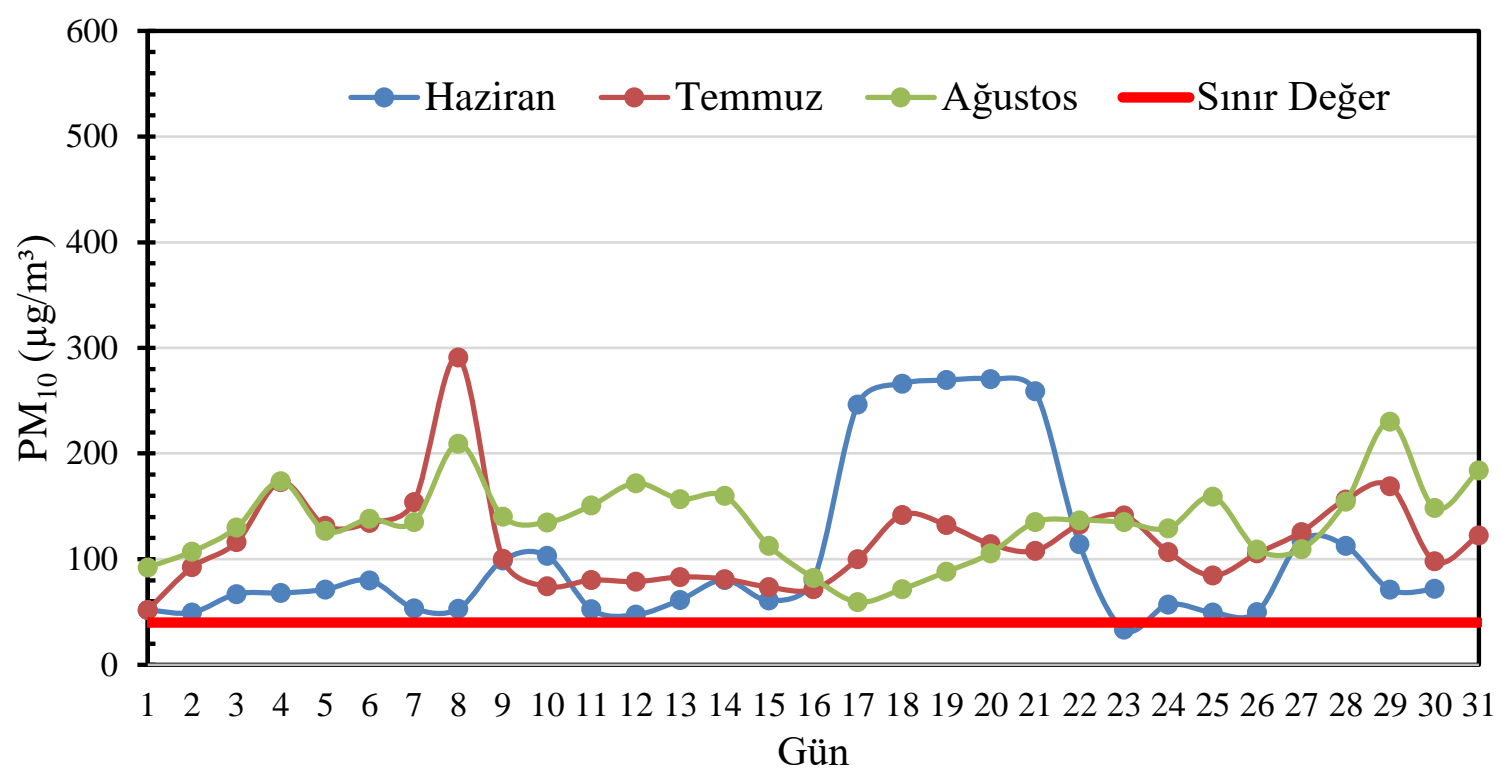

Şekil 3.5. Partiküler madde miktarının yaz dönemindeki değişimi

Çizelge 3.3. Yaz dönemine ait korelasyon katsayıları

\begin{tabular}{|c|c|c|c|c|c|c|}
\hline & Bn & $\mathbf{R y}$ & Hb & $\mathbf{R h}$ & Hs & $\mathbf{P M}_{10}$ \\
\hline Bn & 1.000 & $-.216^{*}$ & $0.213^{*}$ & $-0.254^{*}$ & -0.145 & $0.329^{* *}$ \\
\hline $\mathbf{R y}$ & $-0.216^{*}$ & 1.000 & $0.218^{*}$ & $-0.301 * *$ & $-0.231 *$ & $0.460 * *$ \\
\hline Hb & $0.213^{*}$ & $0.218^{*}$ & 1.000 & $-0.658 * *$ & 0.112 & $0.207 *$ \\
\hline $\mathbf{R h}$ & $-0.254^{*}$ & $-0.301 * *$ & $-0.658 * *$ & 1.000 & 0.035 & $-0.347 * *$ \\
\hline Hs & -0.145 & $-0.231^{*}$ & 0.112 & 0.035 & 1.000 & $-0.399 * *$ \\
\hline PM10 & $0.329 * *$ & $0.460 * *$ & $0.207 *$ & $-0.399 * *$ & $-0.347 * *$ & 1.000 \\
\hline
\end{tabular}

Yaz periyodunda atmosferdeki partiküler madde miktarı, bağıl nem ve hava basınc1 ile benzer eğilimde değişim gösterirken hava sıcaklığı ile $\mathrm{PM}_{10}$ arasında ters orantılı bir değişim gözlenmiştir. Yaz periyodunda Partiler madde konsantrasyonu ile meteorolojik veriler arasındaki ilişkiler Şekil 3.6'da verilmiştir.
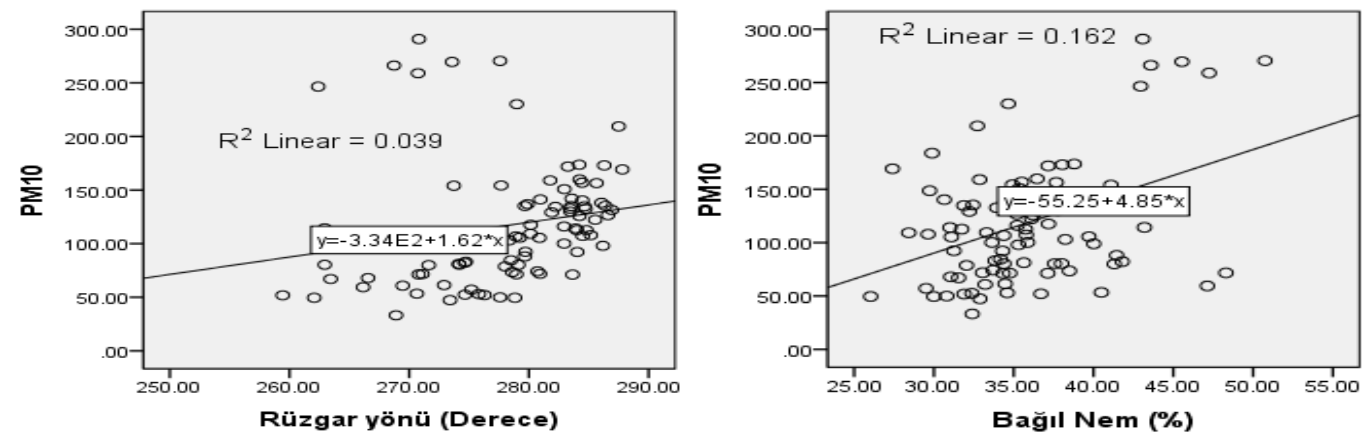
Karakteristikleri: Iğdır Örneği
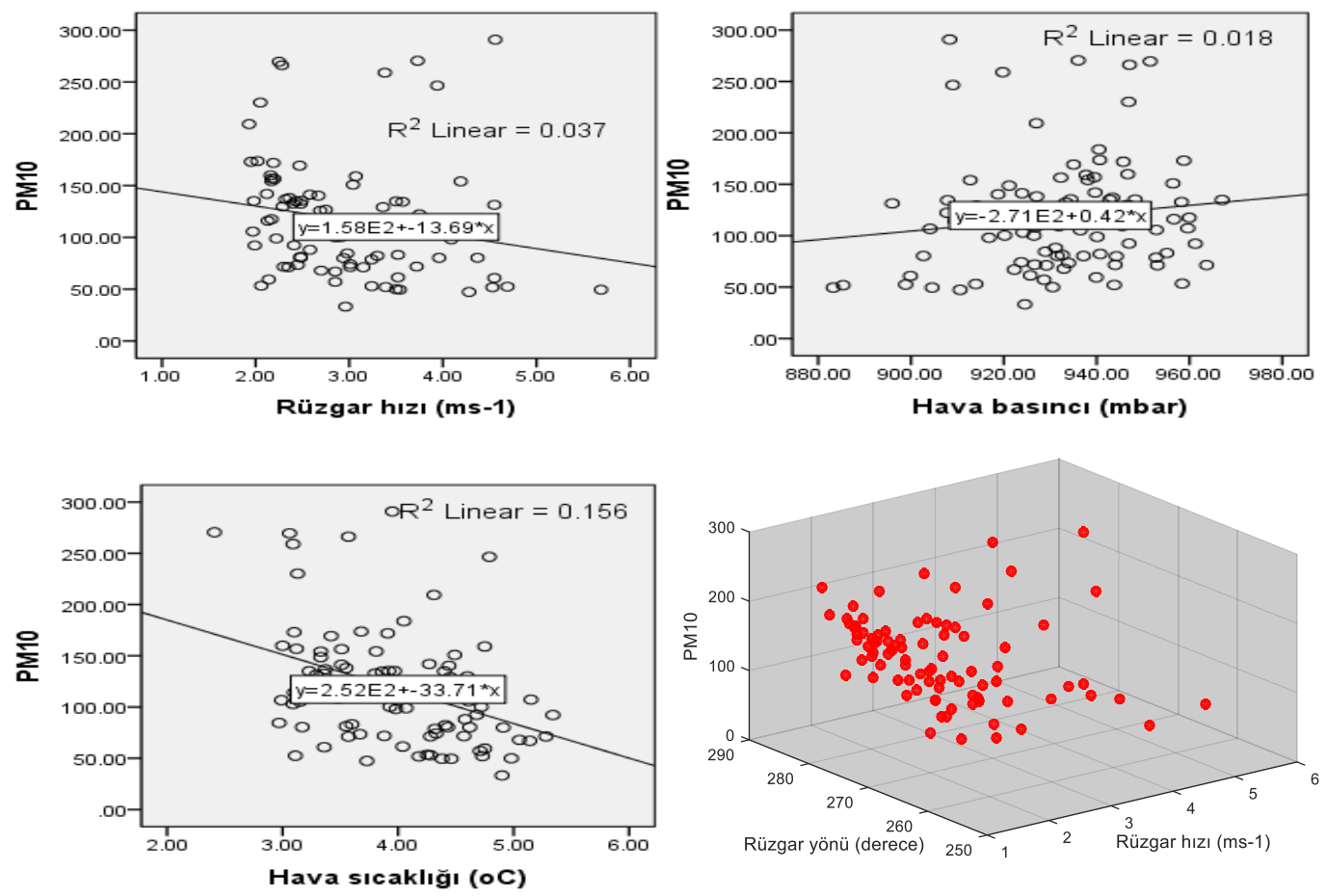

Şekil 3.6. Yaz periyodunda $\mathrm{PM}_{10}$ konsantrasyonunun meteorolojik faktörlerle değişimi

\subsection{Sonbahar Periyoduna İlişkin Sonuçlar}

Yapilan analizler sonucunda il genelinde $\mathrm{PM}_{10}$ miktarının sonbaharda $23 \mu \mathrm{gm}^{-3}$ ile $480{\mu \mathrm{gm}^{-3}}^{-3}$ arasında değiştiği ve mevsim boyunca ortalama $181{\mu \mathrm{gm}^{-3}}^{-3}$ değerinde olduğu belirlenmiş ve sadece dört defa $\mathrm{PM}_{10}$ sınır değeri olarak kabul edilen 40 $\mu^{-3}{ }^{-3}$ 'ün altında kalmıştır (Şekil 3.7). Sonbahar dönemine ait korelasyon katsayıları incelendiğinde rüzgâr hızı ile $\mathrm{PM}_{10}$ miktarı değişim arasında çok kuvvetli, hava basıncı ile partiküleler madde miktarı arasında ise ortaya yakın zayıf bir korelasyon belirlenmiştir (Çizelge 3.4).

Rüzgâr hızı ile $\mathrm{PM}_{10}$ miktarı arasında ters bir ilişki belirlenirken, $\mathrm{PM}_{10}$ ile hava basıncı arasında doğru orantılı bir değişim gözlenmiştir (Şekil 3.8). Ayrıca bağıl nem ve rüzgâr yönü ile $\mathrm{PM}_{10}$ arasındaki negatif korelasyon mevsim boyunca devam etmiştir. Buna ilaveten, hava sıcaklığı ile atmosferdeki kirlilik düzeyi arasında pozitif bir korelasyon olduğu da Çizelge 3.4'den anlaşılmaktadır. Sonbahar periyodundaki partiküler madde miktarı ile meteorolojik faktörler arasındaki ilişkiler Şekil 3.8'de verilmiş̧ir. 
Mikroklima Özelliğine Sahip İklim Koşullarında Meteorolojik Verilerle İlişkili Partiküler Kirlilik $\left(\mathrm{PM}_{10}\right)$ Karakteristikleri: Iğdır Örneği

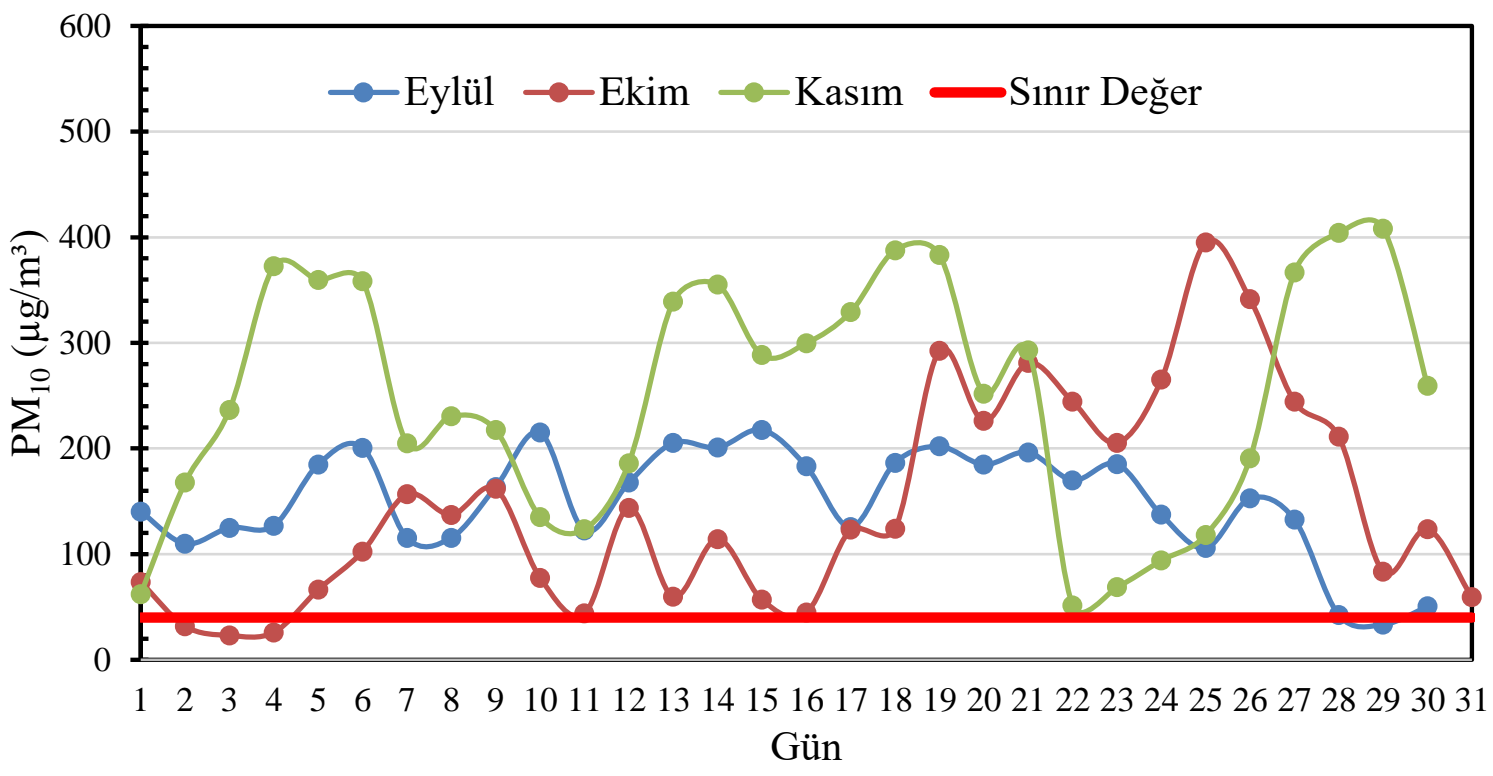

Şekil 3.7. Sonbaharda partiküler madde miktarındaki değişim.

Çizelge 3.4. Sonbahar dönemine ait korelasyon katsayıları

\begin{tabular}{|c|c|c|c|c|c|c|}
\hline & Bn & $\mathbf{R y}$ & Hb & $\mathbf{R h}$ & Hs & $\mathbf{P M}_{10}$ \\
\hline Bn & 1.000 & $0.317 * *$ & -0.006 & 0.033 & $-0.221 *$ & $-0.268^{*}$ \\
\hline Ry & $0.317 * *$ & 1.000 & $-0.343 * *$ & $0.504 * *$ & $-0.550 * *$ & $-0.309 * *$ \\
\hline Hb & -0.006 & $-0.343 * *$ & 1.000 & $-0.608 * *$ & $0.265^{*}$ & $0.408 * *$ \\
\hline $\mathbf{R h}$ & 0.033 & $0.504 * *$ & $-0.608 * *$ & 1.000 & $-0.569 * *$ & $-0.746^{* *}$ \\
\hline Hs & $-0.221 *$ & $-0.550 * *$ & $0.265^{*}$ & $-0.569 * *$ & 1.000 & $0.386 * *$ \\
\hline $\mathrm{PM}_{10}$ & $-0.268^{*}$ & $-0.309 * *$ & $0.408 * *$ & $-0.746 * *$ & $0.386 * *$ & 1.000 \\
\hline
\end{tabular}
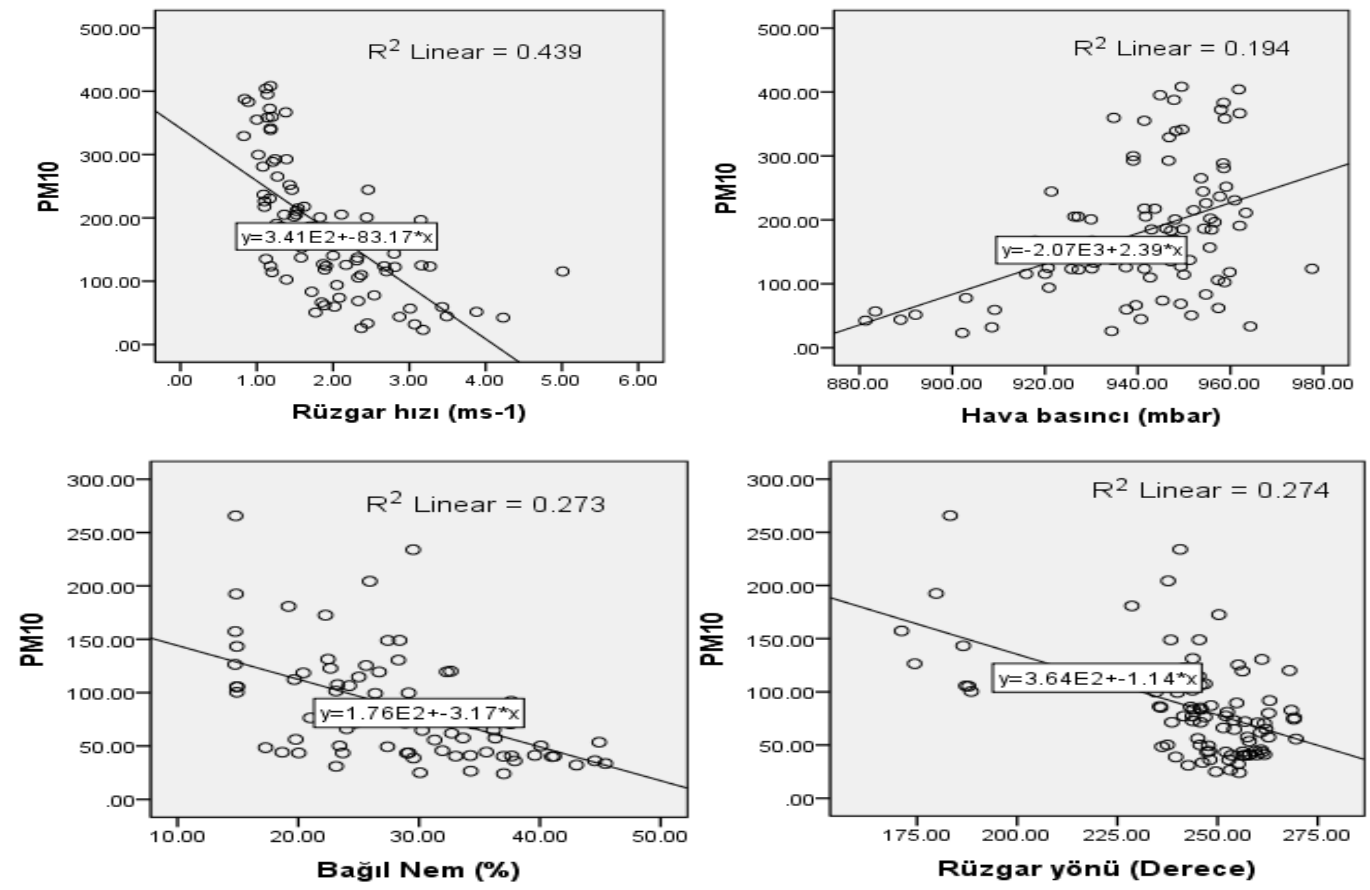

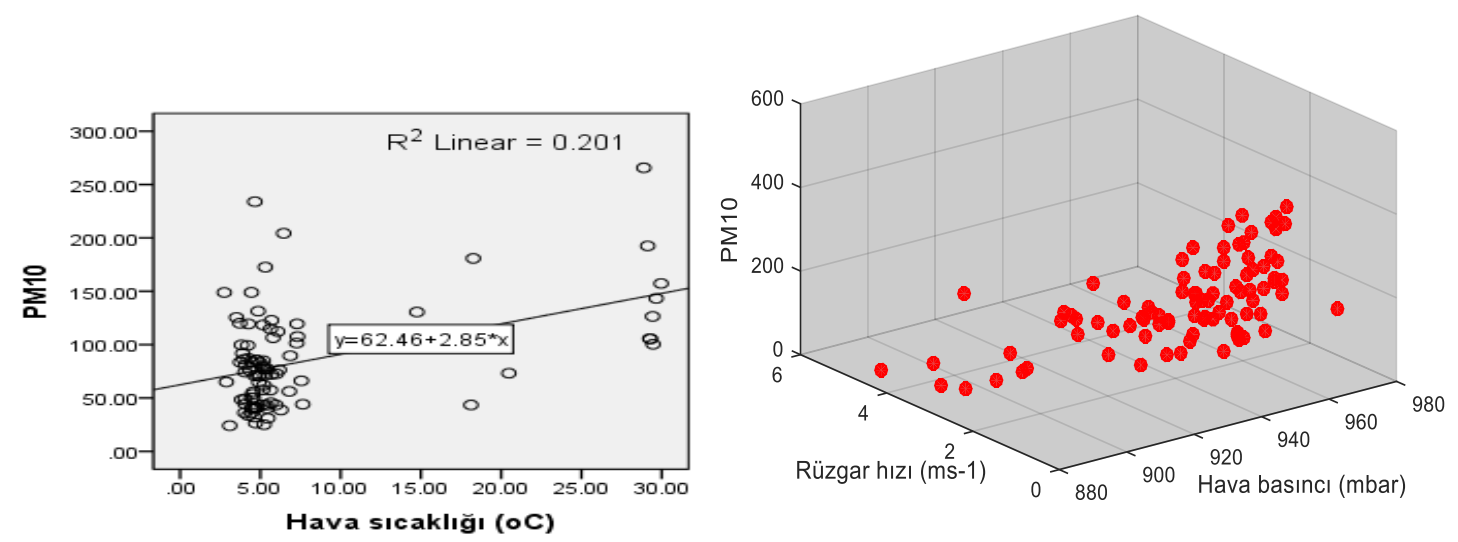

Şekil 3.8. Sonbahar periyodunda $\mathrm{PM}_{10}$ konsantrasyonunun meteorolojik faktörlerle değişimi

\section{Sonuçlar ve Tartışma}

Araştırmada; kış periyodunda ortalama $\mathrm{PM}_{10}$ miktar1 $164.7 \quad \mu \mathrm{gm}^{-3}$ olarak belirlenmiştir. Bu periyotta hava basıncı ve rüzgâr hızı ile $\mathrm{PM}_{10}$ miktarı arasında kuvvetli korelasyonlar olduğu tespit edilmiştir. $\mathrm{PM}_{10}$ konsantrasyonu rüzgâr hızının artmasına bağlı azalma, hava basıncının artmasıyla da artma eğilimi göstermiştir.

İlkbahar döneminde ortalama $\mathrm{PM}_{10}$ miktarı $84 \mu^{-3}$ olduğu belirlenmiştir. Yapılan korelasyon testlerinde bu dönemde partiküler kirliliğe neden olan en önemli meteorolojik faktörlerin bağıl nem ve rüzgâr yönü olduğu tespit edilmiştir. Bağıl nem ve rüzgâr yönündeki azalma ile atmosferdeki $\mathrm{PM}_{10}$ miktarı da azalmıştır.

Yaz periyodunda il genelinde $\mathrm{PM}_{10}$ miktarının ortalama değeri $117{\mu \mathrm{gm}^{-3}}^{-3}$ olarak belirlenmiştir. Korelasyon katsayılarına göre partiküler madde miktarı ile en fazla ilişkili olan meteorolojik faktörlerin rüzgâr yönü ve rüzgâr hızı olduğu ve $\mathrm{PM}_{10}$ miktarındaki değişimin bu parametrelerle doğru orantılı bir seyir takip ettiği belirlenmiştir.

Sonbahar periyodundaki ortalama $\mathrm{PM}_{10}$ miktarı $181 \mu \mathrm{gm}^{-3}$ olup bu değer ile rüzgâr hızı ve hava basıncı arasında kuvvetli bir korelasyon olduğu belirlenmiştir. Araştırmada sonbahar döneminde $\mathrm{PM}_{10}$ miktarı rüzgâr hızı ile ters, hava basıncı ile doğru orantılı bir şekilde değişmiştir.

Yapılan birçok araştırmada rüzgâr hızının partiküler madde konsantrasyonuna etkili olan parametreler arasında önemli bir yere sahip olduğu vurgulanmaktadır (Zobeck and Fryrear, 1986; Zobeck, 1991; Yin et al., 2007). Bunun yanı sıra bağıl nemin de atmosferdeki partikül madde seviyesi üzerine etkili olduğu bilinmektedir (Ravi et al., 2004; Ravi and D'Odorico, 2005; Karar and Gupta, 2006; Ravi et al., 2006; Shah et al., 2006; Vassilakos et al., 2007; Giri et al., 2008; Neuman and Sanderson, 2008). Ravi et al. (2004) yaptıkları araştırmada partikül madde emisyonu ile atmosferdeki bağıl nem düzeyi arasında pozitif yönlü bir korelasyonun olduğunu belirtmişlerdir. Bununla birlikte Ravi and D'Odorico, (2005) ve Ravi et al. (2006) çalışmalarında bağıl nem miktarının çok fazla olması durumunda partiküler madde konsantrasyonu ile bağıl nem arasında ters bir orantının olduğunu belirtmişlerdir.

Iğdır'da mevcut $\mathrm{PM}_{10}$ kirliliği Iğdır'ın yüksek hava basıncına, düşük yıllık ortalama yağış yüksekliğine ve etrafındaki yükseltiler dolayısıyla rüzgâr hızının kesilmesi sonucu düşük rüzgâr hızına bağlanabilir. Kış ve sonbahar dönemlerinde partikül madde kirliliğinin büyük oranda 
ısınma kaynaklı yakıt tüketimi olduğu sonucuna varılmıştır. Çünkü elde edilen bulgularda kış ve sonbahar döneminde $\mathrm{PM}_{10}$ üzerine en etkili faktörler hava basınc1 ve rüzgâr hızıdır. Yüksek atmosferik basınç ve düşük rüzgâr hızı ile bacalardan çıkan partikül maddeler dağılamamakta ve bir örtü gibi şehrin üzerinde kalmaktadır. Ayrıca bu dönemde rüzgâr yönü batı kaynaklıdır ve Ağrı Dağı tarafından dağılım engellenmektedir. Diğer taraftan bağıl nem yalnızca ilkbahar sezonunda $\mathrm{PM}_{10}$ kirliliği üzerine etkin bulunmuştur. Iğdır meteoroloji verileriyle uyumlu bir şekilde ilin Türkiye ortalamasının altında olsa dahi yağışın en yüksek olduğu dönemi ilkbahar sezonudur. Yağışlar ile partikül madde wash-out (bulut altı) mekanizması sayesinde y1kanmaktadır. İlkbahar döneminin bir diğer etkili parametresi rüzgâr yönüdür. Kışın batı kaynaklı rüzgârlarının yerini ilkbahardan itibaren doğu kaynaklı rüzgârlar almaktadır. Özellikle yaz mevsiminde partikül madde kirliliğinin rüzgâr yönü ve hızına bağlı olması, doğu kaynaklı rüzgarlar sebebiyle ilin doğusunda yer alan Aralık ilçesinde mevcut çölleşmenin sonucu olduğu düşünülmektedir.

Mevcut $\mathrm{PM}_{10}$ kirliliğinin azaltılması ya da önlenmesi için; kış ve sonbahar sezonunda 1sınma kaynaklı kirliliğin önlenmesi için doğalgaz dönüşümünün hızlandırılması, doğalgaza geçmemiş konutlar için kaliteli yakıt kullanımının sağlanması, oldukça önem arz etmektedir. Ayrıca; yağışın az olduğu kurak dönemlerde belediyenin etkin bir şekilde araçların geçiş güzergâhlarını sulaması, ilin özellikle batı kısmında konuşlanmış maden çıkarma ve işleme tesislerinin (büyük çoğunluğu kum-çakıl kırma-eleme, pomza, bazalt ve hazır beton tesisidir) denetimlerinin artırılması alınacak diğer önlemler arasındadır. Buna ilaveten; Aralık ilçesindeki rüzgâr erozyonunun önlenmesi için acil olarak bu alanların tarıma açılması ya da ağaçlandırılması gerekmektedir.

\section{Kaynaklar}

Akyüz, M., Çabuk, H., 2009. "Meteorological Variations of $\mathrm{PM}_{2.5} / \mathrm{PM}_{10}$ Concentrations and Particle-Associated Polycyclic Aromatic Hydrocarbons in the Atmospheric Environment of Zonguldak, Turkey", J. Hazard. Mate,. 170, 13-21.

Bai Yun, Yong Li, Xiaoxue Wang, Jingjing Xie and Chuan Li 2016. "Air Pollutants Concentrations Forecasting Using Back Propagation Neural Network Based on Wavelet Decomposition with Meteorological Conditions", Atmospheric Pollution Research, 7(3), 557-566.

Ceylan, Z. and Bulkan S., 2018. "Forecasting $\mathrm{PM}_{10}$ Levels Using ANN and MLR: A Case Study for Sakarya City. Global NEST Journal, 20 (2), 281-290.

Choi, Y.S., Ho, C.H., Chen, D., Noh, Y.H. and Song, C.K., 2008. "Spectral Analysis of Weekly Variation in $\mathrm{PM}_{10}$ Mass Concentration and Meteorological Conditions over China", Atmos. Environ., 42, 655-666.

ÇŞB (Çevre ve Şehircilik Bakanlığı), 2018. T.C. "Çevre ve Şehircilik Bakanlığı Ulusal Hava İzleme A ğı" http://www.havaizleme.gov.tr/Services/Air Quality\# erişim tarihi: 11/11/2018.

Garcia-Menendez, F., Saari, R.K., Monier, E., Selin, N.E, 2015. "U.S. Air Quality and Health Benefits from Avoided Climate Change under Greenhouse Gas Mitigation", Environ. Sci. Technol, 49, 7580-7588.

Giri, D., Krishna, M.V., Adhikari, P.R., 2008. The influence ofmeteorological 
conditions on PM10 concentrations in Kathmandu Valley. Int $J$ Environ Res.,2,49-60.

Januchs, M.G.C., Dominguez. J.Q., Corona, A.V. and Andina, D., 2015. Development of a Model for Forecasting of $\mathrm{PM}_{10}$ Concentrations in Salamanca, Mexico. Atmospheric Pollution Research, 6: 626634.

Karar, K., Gupta, A.K., 2006. Seasonal variations and chemical characterization of ambient PM10 at residential and industrial sites of an. urban region of Kolkata (Calcutta) India. AtmosRes., 81,36-53.

Kolehmainen, M., Martikainen, H. and Ruuskanen, J., 2001. "Neural Networks and Periodic Components Used in Air Quality Forecasting", Atmospheric Environment, 35, 815-825.

Liu, Y., Park, R.J., Jacob, D.J., Li, Q., Kilaru, V. and Sarnat, J.A., 2004. "Mapping Annual Mean Ground-Level $\mathrm{PM}_{2.5}$ Concentrations Using Multiangle Imaging Spectroradiometer Aerosol Optical Thickness over The Contiguous United States", J. Geophys,. Res. 109, 1-10.

Maraziotis, M., Sarotis, S., Marazioti, C. and Marazioti, P., 2008. Statistical analysis of inhalable (PM10) and fine particles (PM2.5) concentrations in urban region of Patras, Greece. Global NEST Journal, 10: (2), 123-131.

Neuman, C.M., Sanderson, S., 2008. Humidity control of particle emissions in aeolian systems. J. Geophys Res Earth Surf .,113, F02 S14.

Ravi, S. and D'Odorico, P. A, 2005. Fieldscale analysis of the dependence ofwind erosion threshold velocity on air humidity. Geophys Res Lett, 32.
Ravi, S., D'Odorico, P, Over, T.M., Zobeck, T.M., 2004. On the effect of air humidity on soil susceptibility to wind erosion: The case of air-dry soils. Geophys Res Lett, 31.

Ravi, S., Zobeck, T.M., Over, T.M., Okin, G.S,, D'Odorico, P., 2006. On the effect of moisture bonding forces in air-dry soils on threshold friction velocity of wind erosion. Sedimentology,53,597-609.

Shah, M.H., Shaheen, N.N., Jaffar, M., 2006. Characterization, source identification and apportionment of selected metals in TSP in an urban atmosphere. Environ Monit Assess, 114,573-87.

Tambo, E., Duo-Quan, W. and Zhou, X.N., 2016. Tackling Air Pollution and Extreme Climate Changes in China: Implementing The Paris Climate Change Agreement. Environ. Int., 95, 152-156.

Tian,G., Qiao, Z. and Xu, X., 2014. "Characteristics of Particulate Matter $\left(\mathrm{PM}_{10}\right)$ and Its Relationship with Meteorological Factors During 2001-2012 In Beijing". Environmental Pollution, 192: 266-274.

Vassilakos, C., Veros, D., Michopoulos, J., Maggosa, T., O'Connor, C.M., 2007. Estimation of selected heavy metals and arsenic in $\mathrm{PM}_{10}$ aerosols in the ambient air of the Greater Athens Area Greece. J Hazard Mater, 140,389-98.

Yin, D., Nickovic, S., Sprigg,W., 2007. The impact of using different land cover data on wind-blown desert dust modeling results in the southwestern United States. Atmos Environ 41, 2214-24.

Zheng, J., Jiang, P., Qiao, W., Zhu, Y., and Kennedy, E., 2016. "Analysis of air pollution reduction and climate change mitigation in the industry sector of Yangtze 
Mikroklima Özelliğine Sahip İklim Koşullarında Meteorolojik Verilerle İlişkili Partiküler Kirlilik $\left(\mathrm{PM}_{10}\right)$

Karakteristikleri: Iğdır Örneği

River Delta in China", J. Clean. Prod., 114, 314-322.

Zobeck, T.M. and Fryrear, D.W., 1986. Chemical and physical characteristics of wind blown sediment II: chemical characteristics and total soil and nutrient discharge. Trans ASAE 129, 1037-41.

Zobeck, T.M., 1991. Soil properties affecting wind erosion. J Soil Water Conserv 46,112-8. 